P-ISSN : 1978-7227 E-ISSN : 2615-3017

dol : https://doi.org/10.30598/barekengvol13iss2pp093-106ar810

Terakreditasi Nasional Peringkat 3 (SINTA 3) sesuai SK. Nomor: 34/E/KPT/2018

\title{
PENGELOMPOKKAN DAN PEMETAAN KARAKTERISTIK KEMISKINAN DI KABUPATEN MALUKU BARAT DAYA PROVINSI MALUKU DENGAN MENGGUNAKAN SELF-ORGANIZING MAP DAN ANALISIS BIPLOT
}

\section{Clustering and Mapping The Characteristics Of Poverty In Southwest Moluccas Regency Moluccas Province Using Self-Organizing Map and Biplot Analysis}

\author{
Z. A. Leleury $^{1 *}$, B. P. Tomasouw ${ }^{2}$ \\ 1,2 Jurusan Matematika, Fakultas Matematika dan Ilmu Pengetahuan Alam, Universitas Pattimura \\ Jln. Ir. M. Putuhena, Kampus Unpatti, Poka-Ambon, 97233,Maluku, Indonesia \\ e-mail: 1*zetharthur82@gmail.com ; 2 bptomasouw@gmail.com \\ Corresponding author*
}

\begin{abstract}
Abstrak
Berdasarkan hasil survei sosial ekonomi nasional (SUSENAS) BPS Provinsi Maluku menunjukkan bahwa kabupaten Maluku Barat Daya (MBD) merupakan kabupaten yang memiliki persentase tingkat kemiskinan tertinggi di Provinsi Maluku dengan persentase tingkat kemiskinan 30,18 persen. Penelitian ini bertujuan untuk melakukan pengelompokkan desa/kecamatan di Kabupaten MDB guna melihat karakteristik kemiskinan pada setiap cluster. Selain itu, juga dilakukan pemetaan karakteristik kemiskinan untuk setiap desa/kecamatan di Kabupaten MBD sebagai upaya untuk mengetahui keragaman karakteristik kemiskinan. Metode pengelompokkan yang digunakan adalah algoritma jaringan syaraf tiruan Self Organizing Map (SOM) dan Biplot. Hasil penelitian memperlihatkan bahwa hasil pengelompokkan terbaik adalah dengan metode Biplot karena memiliki rasio yang lebih kecil. Adapun hasil pengelompokkan 17 kecamatan di kabupaten MBD terbagi dalam 4 cluster yakni cluster 1 terdiri kecamatan Pulau-Pulau Terselatan, Letti dan Moa; cluster 2 terdiri dari kecamatan Pulau-Pulau Babar dan Babar Timur; cluster 3 terdiri dari kecamatan Pulau Masela, Mdona Hyera, Kepulauan Romang, Damer, Wetar, dan Wetar Barat; sedangkan cluster 4 terdiri dari kecamatan Wetar Utara, Wetar Timur, Kisar Utara, Lakor, Dawelor Dawera dan Pulau Wetang. Ada 11 faktor yang mempengaruhi sehingga cluster 4 tergolong dalam cluster dengan karakteristik kemiskinan tertinggi. Sedangkan ada 4 faktor yang mempengaruhi sehingga cluster 3 tergolong dalam cluster dengan karakteristik kemiskinan cukup tinggi.
\end{abstract}

Kata Kunci : Biplot, Cluster, Karakteristik Kemiskinan, MBD, Self Organizing Map.

\begin{abstract}
Based on the results of the national socio-economic survey by Badan Pusat Statistik of Moluccas Province shows that the Southwest Moluccas regency is a regency that has the highest percentage of poverty rates in Moluccas Province with a percentage of poverty rates 30.18 percent. This research is aimed to cluster villages/subdistricts in Southwest Moluccas district to see the characteristics of poverty in each cluster. In addition, the mapping of poverty characteristics for each village/subdistrict in the Southwest Moluccas district was also carried out in an effort to find out the diversity of characteristics of poverty. The clustering method used is the Self Organizing Map (SOM) and Biplot Analysis. The result show that the best clustering are obtained from the Biplot method because it had a smaller ratio. The results of the grouping of 17 subdistricts in the Southwest Molucass district are divided into 4 clusters, namely cluster 1 consisting of Pulau-Pulau Terselatan, Letti and Moa; cluster 2 consists of PulauPulau Babar and Babar Timur; cluster 3 consists of Pulau Masela, Mdona Hyera, Kepulauan Romang, Damer, Wetar, and Wetar Barat; while cluster 4 consists of Wetar Utara, Wetar Timur, Kisar Utara, Lakor, Dawelor Dawera and Pulau Wetang. There are 11 factors that influence so cluster 4 belongs to the cluster with the highest characteristics of poverty. Whereas there are 4 factors that influence so cluster 3 is classified as a cluster with high characteristics of poverty.
\end{abstract}

Keywords: Biplot, Characteristics of Poverty, Cluster, Southwest Moluccas, Self Organizing Map 


\section{PENDAHULUAN}

Kemiskinan merupakan sebuah permasalahan sosial yang sangat kompleks dan harus segera mendapat penanganan yang tepat agar dapat segera teratasi. Badan Pusat Statistik (BPS), sebagai salah satu instansi pemerintah yang diberikan kewenangan dalam penyediaan data dan informasi kemiskinan di Indonesia, menggunakan pendekatan kebutuhan dasar (basic needs approach) dalam penghitungan penduduk miskin. Dengan pendekatan ini kemiskinan didefinisikan sebagai ketidak-mampuan dalam memenuhi kebutuhan dasar atau dengan kata lain kemiskinan dipandang sebagai ketidakmampuan dari sisi ekonomi untuk memenuhi kebutuhan makanan maupun non-makanan yang bersifat mendasar [12]. Berdasarkan pendekatan kebutuhan dasar, indikator yang digunakan adalah head count index yaitu persentase penduduk yang berada dibawah garis kemiskinan. Garis kemiskinan itu sendiri dihitung berdasarkan rata-rata pengeluaran makanan dan non-makanan per kapita pada kelompok referensi (reference population).

Secara nasional, sesuai hasil rilis BPS tahun 2017, provinsi Maluku menempati urutan keempat sebagai daerah termiskin di Indonesia dengan persentase tingkat kemisikinan 19,26\%. Sementara, berdasarkan hasil survei sosial ekonomi nasional (SUSENAS) BPS Provinsi Maluku menunjukkan bahwa kabupaten Maluku Barat Daya (MBD) merupakan kabupaten yang memiliki persentase tingkat kemiskinan tertinggi di Provinsi Maluku dengan persentase tingkat kemiskinan 30,18 persen. Kabupaten MBD yang beribukota di Tiakur, secara administratif terbagi menjadi 17 Kecamatan dengan 117 desa dimana sebagian besar penduduknya memiliki mata pencaharian berupa nelayan dan petani [2].

Penentuan garis kemiskinan yang dikeluarkan oleh BPS menjadi salah satu dasar untuk melihat apakah seseorang dapat dikategorikan miskin atau tidak miskin. Garis kemiskinan tersebut akan dibandingkan dengan rata-rata pengeluaran per kapita penduduk desa. Desa/kelurahan yang memiliki ratarata pengeluaran per kapita penduduk kurang dari garis kemiskinan, dianggap sebagai desa tertinggal, sedangkan yang lebih dari atau sama dengan garis kemiskinan, dianggap sebagai desa/kelurahan tidak tertinggal. Dalam penelitian ini, dilakukan pengelompokkan desa/kecamatan di Kabupaten MBD menggunakan model jaringan syaraf tiruan Self Organizing Map (SOM) dan Biplot. Selanjutnya dilakukan perbandingan dari hasil pengelompokkan yang diperoleh untuk menentukan pengelompokkan terbaik. Pengelompokkan ini berdasarkan variabel karakteristik kemiskinan yang diteliti agar dapat diketahui kedekatan antar desa/kecamatan dalam suatu cluster dan keragaman karakteristik kemiskinan.

\subsection{Self Organizing Map}

Jaringan SOM merupakan salah satu jaringan saraf yang disukai untuk analisis pengelompokkan. Titik kunci dari algoritma SOM adalah dengan perhitungan geometri. Jaringan SOM menggunakan metode pembelajaran unsupervised. Pada jaringan ini, suatu lapisan yang berisi neuron-neuron akan menyusun dirinya sendiri berdasarkan input nilai tertentu dalam suatu kelompok yang dikenal dengan istilah cluster. Selama proses penyusunan diri, cluster yang memiliki vektor bobot paling cocok dengan pola input (memiliki jarak paling dekat) akan terpilih sebagai pemenang. Neuron yang menjadi pemenang beserta neuron-neuron tetangganya akan memperbaiki bobot-bobotnya [10].

Pada pembelajaran unsupervised, di sini jaringan hanya diberi seperangkat data input saja tanpa adanya target yang diharapkan. Jaringan akan melatih dirinya sendiri untuk bisa mengenali pola data input dan kemudian mengklasifikasikannya. Berapa jumlah kelompok data output tidak ditentukan dan jumlah kelompok data ini bisa terus bertambah tanpa batas. Dalam unsupervised ini, jaringan hanya diberi ramburambu tentang tingkat keseragaman data input saja. Dengan kata lain, jumlah kelompok data yang terbentuk ditentukan oleh tingkat keseragaman data. Jika tingkat keseragaman rendah maka jumlah kelompok data yang dihasilkan akan sedikit dan demikian sebaliknya.

Penelitian [5] menunjukkan bahwa jaringan SOM adalah jaringan saraf kompetitif dan kooperatif yang dapat menampung vektor input dari struktur topologi dan peta data jaringan berdimensi tinggi ke yang lebih rendah. Iatrical scholar menggunakan teknik SOM dan teori himpunan untuk menemukan kecenderungan kondisi pasien penderita penyakit kardiovaskular secara individual [7]. Selain itu, penelitian yang dilakukan oleh [9] dan [13] terkait dengan pemetaan ciri-ciri penyakit untuk diagnosa penyakit menunjukkan bahwa jaringan SOM juga sangat cocok untuk analisis cluster. Jaringan SOM terdiri dari dua lapisan (layer), yaitu lapisan input dan lapisan output. Setiap neuron dalam lapisan input terhubung dengan setiap neuron pada lapisan output. Setiap neuron dalam lapisan output merepresentasikan kelas dari input 
yang diberikan. Adapun langkah-langkah dalam penerapan algoritma SOM yang merupakan kompetisi dan pembelajaran untuk mendapatkan pemenang dalam proses disajikan dalam bentuk diagram alir berikut:

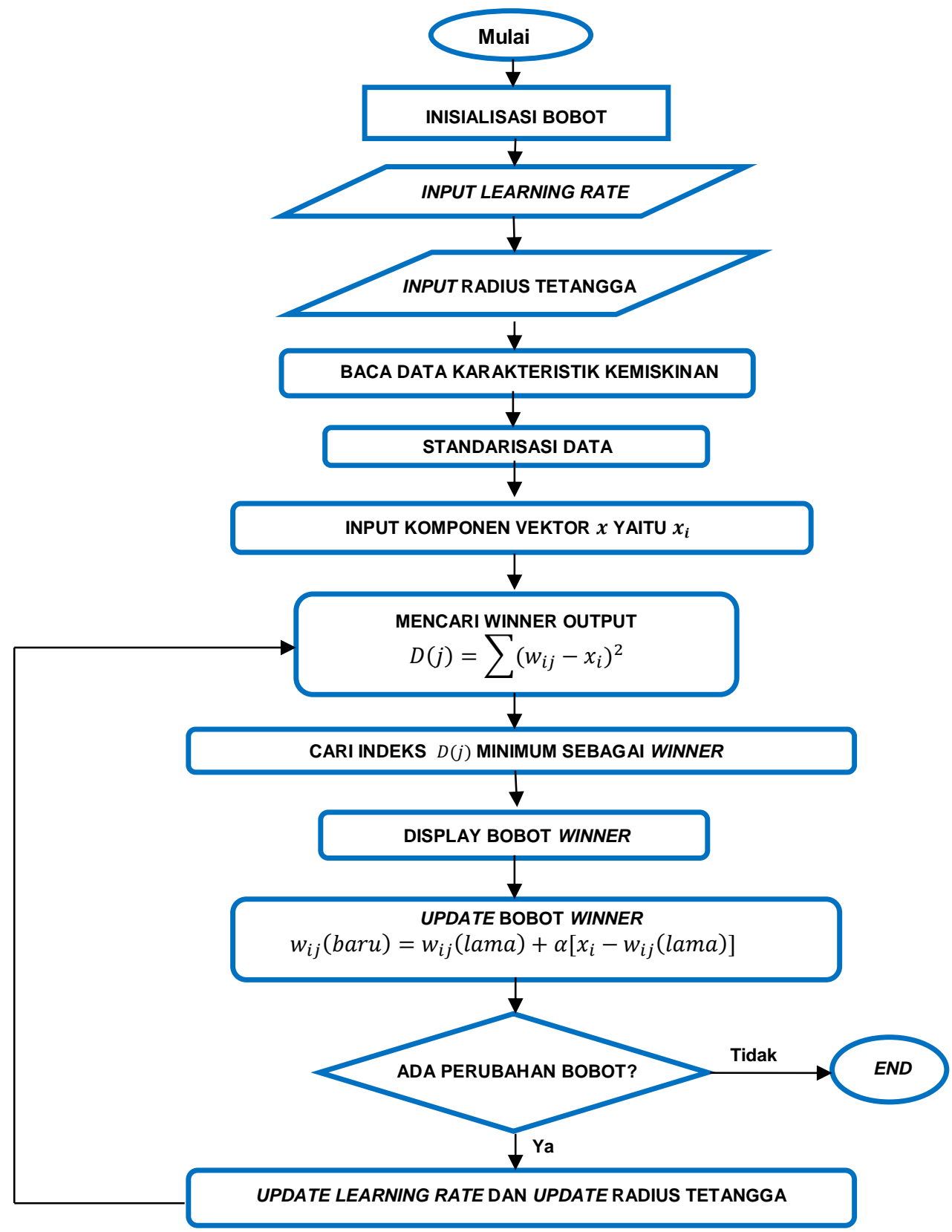

Gambar 1. Diagram Alir Jaringan SOM

\subsection{Analisis Biplot}

Biplot adalah salah satu upaya mengambarkan data-data yang ada pada tabel ringkasan dalam grafik berdimensi dua. Informasi yang diberikan oleh biplot mencakup objek dan variabel dalam satu gambar [6]. Berdasarkan tampilan biplot yang disajikan secara visual dan simultan sejumlah objek pengamatan dan variabel dalam suatu grafik, maka ada empat hal penting yang bisa diperoleh, yakni kedekatan antar objek yang diamati, keragaman variabel, korelasi antar variabel dan nilai variabel pada suatu objek [1].

Analisis biplot adalah suatu metode multivariat yang mengunakan baris dan kolom dalam suatu grafik. Metode ini digunakan untuk menampilkan variabel dan objek yang diteliti. Bilpot merupakan teknik statistik deskriptif dimensi ganda yang dapat menyajikan secara simultan segugus objek pengamatan dan variabel dalam suatu grafik pada suatu bidang datar sehingga ciri-ciri variabel dan objek pengamatan serta posisi relatif antara objek pengamatan serta posisi relatif antara objek pengamatan dengan variabel dapat 
dianalisis. Penyajian plot objek pengamatan dan variabel secara bersamaan ini juga dapat memberikan tambahan informasi yang lebih baik tentang hubungan antara variabel dan pengamatan [8].

Analisis Biplot didasarkan pada Singular Value Decomposisition (SVD). SVD bertujuan menguraikan matriks $X$ berukuran $n \times p$ dimana $n$ adalah banyaknya objek pengamatan dan $p$ adalah banyaknya variabel, menjadi 3 buah matriks. Persamaan yang digunakan adalah matriks berukuran $n \times p$ yang berisi $n$ objek dan $p$ variabel, dapat ditulis:

$$
X=U L A^{\prime}
$$

Dengan:

$X=$ Matriks data berukuran $n \times p$

$U=$ Matriks berukuran $n \times R$ yang kolom-kolomnya disebut vektor singular kolom .

$L=$ Matriks diagonal berukuran $r \times r$ dengan unsur diagonal utamanya adalah nilai singular matriks $X$, yaitu akar kuadrat dari nilai eigen matriks $X^{\prime} X$

$A=$ Matriks berukuran $p \times r$ yang kolom-kolomnya adalah vektor eigen dari matriks $X^{\prime} X$

$U$ dan $A$ adalah matriks orthonormal, dimana $U^{\prime} U=A^{\prime} A=I X^{\prime} X=I$ dan $X^{\prime} X=I, U$ adalah kolom dari $A^{\prime}$ berisi eigen vektor dari matriks $X^{\prime} X$ dan matriks diagonal dari $L$ yang berisi akar kuadrat dari nilai eigen $X^{\prime} X$ atau $X X^{\prime}$, sehingga $\sqrt{\lambda_{1}} \geq \sqrt{\lambda_{2}} \geq \cdots \geq \sqrt{\lambda_{r}}$ unsur-unsur diagonal matriks $L$ disebut nilai singular dari matriks $X$ dan kolom-kolom matriks $A$ adalah vektor eigen dari $X^{\prime} X$ atau $X X^{\prime}$ yang berpadanan dengan $\lambda$. $L^{\alpha}$ untuk $0 \leq \alpha \leq 1$ merupakan matriks diagonal berukuran $r \times r$ dengan unsur-unsur diagonalnya $\lambda_{1}^{\alpha / 2}, \lambda_{2}^{\alpha / 2}, \ldots, \lambda_{r}^{\alpha / 2}$. Definisi $L^{\alpha}$ berlaku juga untuk $L^{1-\alpha}$, sehingga diperoleh unsur - unsur diagonalnya $\lambda_{1}^{1-\alpha / 2}, \lambda_{2}^{1-\alpha / 2}, \ldots, \lambda_{r}^{1-\alpha / 2}$. Misalkan $U L^{\alpha}$ dan $H^{\prime}=L^{1-\alpha} A^{\prime}$ dengan $0 \leq \alpha \leq 1$. Persamaan matriks $X$ dapat ditulis menjadi

$$
X=U L^{\alpha} L^{1-\alpha} A^{\prime}=G H^{\prime}
$$

Matriks $G$ skor komponen utama yang merupakan titik-titik koordinat dari $n$ objek dan matriks $H$ memuat vektor eigen yang merupakan titik-titik koordinat dari $p$ peubah. Gambaran biplot dari matriks data $X$ diperoleh dengan mengambil dua kolom pertama dari matriks $G$ dan dua kolom pertama dari matriks $H$.

Ada dua nilai $\alpha$ yang digunakan untuk mendefenisikan $G=U L^{\alpha}$ dan $H^{\prime}=L^{1-\alpha} A^{\prime}$ yaitu $\alpha=0$ dan $\alpha=1$. Jika $\alpha=0$, maka diperoleh persamaan sebagai berikut:

$$
G=U \text { dan } H^{\prime}=L A^{\prime}
$$

Secara keseluruhan pemilihan $\alpha=0$, akan memberikan kesesuaian untuk data keragaman. Tampilan biplot akan lebih mampu menggambarkan keragaman variabel, hubungan antar variabel sekaligus mendapatkan informasi mengenai pola objek. Jika $\alpha=0$ yang digunakan, maka hasil pemfaktoran disebut Column Metric Preserving (CMP)biplot. Jika $\alpha=1$, maka diperoleh persamaan : $G=U L$ dan $H^{\prime}=A^{\prime}$ Dengan mengunakan $\alpha=1$, tampilan biplot akan lebih memberikan gambaran jarak antara pasangan barisan sehingga baik digunakan untuk melihat kedekatan objek-objek. Jika $\alpha=1$ yang digunakan, maka hasil pemfaktoran Row Metric Preserving (RMP) biplot [11].

\section{METODE PENELITIAN}

\subsection{Sumber Data}

Data yang digunakan untuk penelitian ini bersumber dari hasil survey BPS Tahun 2016 [3] pada setiap desa/kelurahan di 17 kecamatan yang ada di kabupaten MBD.

\subsection{Variabel Penelitian}

Adapun variabel-variabel penelitian yang merupakan karakteristik kemiskinan pada suatu wilayah kecamatan antara lain :

1. Faktor Geografis dan akses

$X_{1}$ : Luas Wilayah Menurut Kecamatan di Kabupaten MBD $\left(\mathrm{Km}^{2}\right)$

$X_{2}$ : Banyak Pulau Menurut Kecamatan di Kabupaten MBD 
$X_{3}$ : Jarak Ibukota Kabupaten MBD dengan ibu Kota Kecamatan (mil)

$X_{4}$ : Banyaknya Desa Menurut Kecamatan di Kabupaten MDB

$X_{5}$ : Luas Areal Padi Ladang Menurut Kecamatan di Kabupaten MBD (Hektar)

$X_{6}$ : Luas Areal Padi Sawah Menurut Kecamatan di Kabupaten MBD (Hektar)

$X_{7}$ : Luas Areal Tanaman Jagung Menurut Kecamatan di MBD (Hektar)

$X_{8}$ : Luas Areal Tanaman Ketela Pohon Menurut Kecamatan di MBD (Hektar)

$X_{9}$ : Luas Areal Tanaman Ketela Rambat Menurut Kecamatan di MBD (Hektar)

$X_{10}$ : Luas Areal Tanaman Kacang Tanah Menurut Kecamatan di MBD (Hektar)

$X_{11}$ : Luas Areal Tanaman Kacang Hijau Menurut Kecamatan di MBD (Hektar)

$X_{12}$ : Luas Tanaman Perkebunan (Kelapa, Cengkih, Pala, Kopi, Kakao dan Jambu Mete) Menurut Kecamatan di MBD (Hektar)

$X_{13}$ : Luas Potensi Lahan Budidaya Laut Menurut Kecamatan di Kabupaten MBD (Hektar)

$X_{14}$ : Panjang Jalan Dalam Kondisi Baik (Aspal) Menurut Kecamatan di Kabupaten MBD (Km)

$X_{15}$ : Panjang Jalan Dalam Kondisi Rusak (Tanah/Belum Tembus) Menurut Kecamatan di Kabupaten $\operatorname{MBD}(\mathrm{Km})$

$X_{16}$ : Panjang Jalan Dalam Kondisi Sedang (Urpil) Menurut Kecamatan di Kabupaten MBD (Km)

2. Faktor Sumber Daya Manusia (SDM) dan Sosial Ekonomi Penduduk

$X_{17}$ : Tingkat Perkembangan Desa (Swadaya, Swakarsa, Swasembada) Menurut Kecamatan Di Kabupaten MBD

$X_{18}$ : Laju Pertumbuhan Penduduk Menurut Kecamatan di Kabupaten MDB(\%)

$X_{19}$ : Kepadatan Penduduk per $\mathrm{Km}^{2}$ Menurut Kecamatan di Kabupaten MBD

$X_{20}$ : Rasio Jumlah Guru dan Banyaknya Sekolah Dasar (SD) Menurut Kecamatan di Kabupaten MBD

$X_{21}$ : Rasio Jumlah Guru dan Banyaknya Sekolah SMP Menurut Kecamatan di Kabupaten MBD

$X_{22}$ : Rasio Jumlah Guru dan Banyaknya Sekolah SMA Menurut Kecamatan di Kabupaten MBD

$X_{23}$ : Rasio Jumlah Guru dan Banyaknya Sekolah SMK Menurut Kecamatan di Kabupaten MBD

$X_{24}$ : Jumlah Tenaga Kesehatan Menurut Kecamatan di Kabupaten MBD

$X_{25}$ : Tenaga Usaha Perbaikan Gizi Keluarga (UPGK) Menurut Kecamatan di Kabupaten MBD

$X_{26}$ : Persentase Status Gizi Buruk Balita Menurut Kecamatan di Kabupaten MBD

$X_{27}$ : Persentase Peserta KB Aktif Terhadap Jumlah Pasangan Usia Subur Menurut Kecamatan di MBD

$X_{28}$ : Produksi Tanaman Perkebunan Menurut Kecamatan di Kabupaten MBD (Ton)

$X_{29}$ : Populasi Ternak Menurut Kecamatan dan Jenis Ternak di Kabupaten MBD

$X_{30}$ : Populasi Unggas Menurut Kecamatan dan Jenis Unggas di Kabupaten MBD

$X_{31}$ : Banyaknya Produksi Rumput Laut Menurut Kecamatan di Kabupaten MBD

3. Sarana dan Prasarana

$X_{32}$ : Jumlah Fasilitas Kesehatan (Puskesmas dan Posyandu) Menurut Kecamatan di Kabupaten MBD

$X_{33}$ : Jumlah Klinik Keluarga Berencana (KKB) dan Pos Pelayanan Keluarga Berencana Desa (PPKBD) Menurut Kecamatan di Kabupaten MBD

$X_{34}$ : Jumlah Perahu/Kapal Menurut Kecamatan di Kabupaten MBD 


$$
\begin{aligned}
& X_{35}: \text { Jumlah Koperasi Menurut Kecamatan di Kabupaten MBD } \\
& X_{36} \text { : Sarana dan Prasarana Perhubungan Laut dan Udara di Kabupaten MBD }
\end{aligned}
$$

Variabel yang terpilih adalah variabel yang secara substansi merupakan karakteristik dan determinan ketertinggalan wilayah dengan memperhatikan ketersediaan data pada kegiatan Survey BPS Tahun 2016. Selanjutnya, untuk pengolahan dan analisis data, digunakan software Matlab dan SPSS.

\subsection{Tahapan Penelitian}

Secara terperinci tahapan metode penelitian yang digunakan dapat dirumuskan sebagai berikut:

a. Pengumpulan dan verifikasi data : pada tahap ini dilakukan pengumpulan dan verifikasi data hasil Survei BPS Tahun 2016 di Kabupaten MBD Propinsi Maluku.

b. Statistika Deskriptif: pada tahapan ini dilakukan pemaparan data dengan angka maupun gambar yang informatif sehingga dapat ditarik suatu kesimpulan sementara akan kondisi pada setiap desa/kecamatan di Kabupaten MBD.

c. Standarisasi Data: pada tahap ini dilakukan tranformasi (standarisasi) data untuk memudahkan proses pengolahan data menjadi informasi dan laporan sehingga hasil cluster tidak bias.

d. Pengelompokkan desa/kecamatan: pada tahapan ini diterapkan algoritma jaringan SOM untuk mengelompokkan setiap desa/kecamatan di Kabupaten MBD berdasarkan beberapa cluster yang ditentukan.

e. Analisis Hasil Clustering: pada tahapan ini dilakukan klasifikasi tingkat kemiskinan berdasarkan cluster yang diperoleh.

f. Pemetaan Biplot: pada tahapan ini dilakukan pemetaan biplot untuk memberikan penyajian visual hasil pemetaan setiap desa/kecamatan dan variabel (karakteristik kemiskinan) pada suatu plot dua dimensi.

g. Analisis biplot: pada tahap ini dianalisis hasil pemetaan (biplot) untuk desa/kecamatan di Kabupaten MBD berdasarkan variabel karakteristik kemiskinan yang diteliti. Ada 4 hal penting yang dapat dianalisis dari tampilan biplot antara lain: kedekatan antar setiap desa/kecamatan serta karakteristik kemiskinan yang mempengaruhi, keragaman karakeristik kemiskinan di Kabupaten MBD dan korelasi antar variabel karakteristik kemiskinan.

\section{HASIL DAN PEMBAHASAN}

\subsection{Deskripsi Data Penelitian}

Peneliti mengunakan 17 kecamatan di Kabupaten Maluku Barat Daya (MBD) sebagai objek penelitian yaitu:
1) Wetar
2) Wetar Barat
7) Kepulauan Romang
3) Wetar Utara
8) Letti
9) Moa
4) Wetar Timur
10) Lakor
5) Pulau-PulauTerselatan
11) Damer
12) Mdona Hyera
6) Kisar Utara
13) Pulau-Pulau Babar
14) Pulau Wetang
15) Babar Timur
16) Pulau Masela
17) Dawelor Dawera

Adapun data deskriptif kemiskinan di Kabupaten MBD (hasil olahan data bersumber dari [4]) disajikan dalam Tabel 1.

Tabel 1. Deskriptif Karakteristik Kemiskinan di Kabupaten MBD

\begin{tabular}{|c|c|c|c|c|}
\hline Karakteristik & Minimum & Maksimum & Rata-rata & Standar Deviasi \\
\hline$X_{1}$ & 16,79 & 1725,24 & 50,75 & 452,232 \\
\hline$X_{2}$ & 0 & 12 & 2,82 & 3,80 \\
\hline$X_{3}$ & 0 & 140 & 77,91 & 45,93 \\
\hline$X_{4}$ & 5 & 16 & 10 & 3,74 \\
\hline$X_{5}$ & 0 & 34 & 2,70 & 8,31 \\
\hline$X_{6}$ & 0 & 0,50 & 0,03 & 0,12 \\
\hline$X_{7}$ & 5 & 1104 & 282,71 & 336,05 \\
\hline$X_{8}$ & 3 & 165 & 30,29 & 41,02 \\
\hline
\end{tabular}




\begin{tabular}{|ccccc|}
\hline$X_{9}$ & 1 & 33 & 5,59 & 7,63 \\
\hline$X_{10}$ & 1 & 32 & 7,76 & 8,97 \\
\hline$X_{11}$ & 1 & 25 & 10,35 & 8,58 \\
\hline$X_{12}$ & 0 & 1952 & 517,58 & 584,11 \\
\hline$X_{13}$ & 0 & 2242,13 & 327,86 & 735,33 \\
\hline$X_{14}$ & 0 & 88,57 & 18,38 & 24,53 \\
\hline$X_{15}$ & 0 & 106,97 & 41,97 & 30,02 \\
\hline$X_{16}$ & 0 & 6,06 & 1,34 & 1,94 \\
\hline$X_{17}$ & 3 & 11 & 6,88 & 2,47 \\
\hline$X_{18}$ & 0,18 & 0,48 & 0,31 & 0,09 \\
\hline$X_{19}$ & 1,36 & 226,10 & 32,73 & 64,49 \\
\hline$X_{20}$ & 2,83 & 9,67 & 5,74 & 1,94 \\
\hline$X_{21}$ & 1,33 & 14,75 & 4,82 & 3,39 \\
\hline$X_{22}$ & 0 & 25 & 6,97 & 7,38 \\
\hline$X_{23}$ & 0 & 18 & 3,24 & 5,29 \\
\hline$X_{24}$ & 5 & 73 & 19,82 & 17,85 \\
\hline$X_{25}$ & 25 & 108 & 53,94 & 25,31 \\
\hline$X_{26}$ & 0 & 11,58 & 4,10 & 3,38 \\
\hline$X_{27}$ & 0 & 35,05 & 12,34 & 12,24 \\
\hline$X_{28}$ & 4,40 & 1281,20 & 333,95 & 399,87 \\
\hline$X_{29}$ & 1501 & 20638 & 7105,47 & 5799,34 \\
\hline$X_{30}$ & 198 & 60223 & 4986,94 & 14270,25 \\
\hline$X_{31}$ & 0 & 78445,44 & 5917,15 & 19193,36 \\
\hline$X_{32}$ & 6 & 22 & 12,71 & 5,27 \\
\hline$X_{33}$ & 0 & 2 & 0,71 & 0,69 \\
\hline$X_{34}$ & 43 & 902 & 219,35 & 200,20 \\
\hline$X_{35}$ & 0 & 25 & 7,12 & 7,78 \\
\hline$X_{36}$ & 0 & 3 & 1,06 & 0,66 \\
\hline & & & & \\
\hline
\end{tabular}

\subsection{Proses Pengelompokan Mengunakan Metode Self Organizing Maps (SOM)}

Penggunaan metode Self Organizing Maps (SOM) untuk mengelompokkan 17 kecamatan di kabupaten MBD berdasarkan data karakteristik kemiskinan dengan parameter yang digunakan dalam jaringan SOM, sebagai berikut:

$\begin{array}{lll}\text { Inisialisasi bobot } w_{i j} & = & 5 \times 10^{8} \\ \text { Learning rate }(\alpha) & = & 0,6 \\ \text { Radius tetangga }(R) & = & 0 \\ \text { Learning rate fase update } & = & 0,01\end{array}$

Hasil pengelompokan untuk 4 cluster dengan 1000 iterasi seperti yang ditampilkan pada Tabel 2 berikut ini:

Tabel 2. Hasil Pengelompokkan Kecamatan di Kabupaten MBD Menggunakan Metode SOM

\begin{tabular}{|c|l|}
\hline Pengelompokan & \multicolumn{1}{c|}{ Anggota } \\
\hline Cluster 1 & PP. Terselatan, Letti, Moa \\
\hline Cluster 2 & PP. Babar, Mdona Hyera, Babar Timur, Kep. Romang, Damer \\
\hline Cluster 3 & Kisar Utara, Lakor, Dawelor Dawera, P. Wetang, P. Masela \\
\hline Cluster 4 & Wetar, Wetar Barat, Wetar Utara, Wetar Timur \\
\hline
\end{tabular}

\subsection{Proses Pengelompokan Mengunakan Metode Biplot}

Informasi data yang disajikan dalam biplot ditentukan berdasarkan nilai $\rho^{2}$, semakin mendekati nilai satu berarti biplot yang diperoleh dari matriks pendekatan berdimensi dua akan memberikan penyajian data yang semakin baik mengenai informasi-informasi yang terkandung pada data yang sebenarnya. Penyajian informasi ini bergantung pada nilai eigen $(\lambda)$. Nilai eigen yang digunakan adalah dua nilai eigen terbesar dari matriks $X^{\prime} X$. Pada penelitian ini diperoleh nilai $\lambda_{1}$ sebesar 10,7436 dan $\lambda_{2} 62,0545$ sehingga diperoleh nilai $\rho^{2}$ adalah 0,7 . Karena nilai $\rho^{2}$ yang diperoleh mendekati 1 , maka biplot yang dihasilkan 
sangat baik. Hasil penggelompokan dengan menggunakan metode biplot adalah seperti yang ditampilkan pada Tabel 3, berikut:

Tabel 3. Hasil Pengelompokkan Kecamatan di Kabupaten MBD Menggunakan Metode Biplot

\begin{tabular}{|c|l|}
\hline Pengelompokan & \multicolumn{1}{c|}{ Anggota } \\
\hline Cluster 1 & PP. Terselatan, Letti, Moa \\
\hline Cluster 2 & PP. Babar, Babar Timur \\
\hline Cluster 3 & P. Masela, Mdona Hyera, Kep. Romang, Damer, Wetar, Wetar Barat, \\
\hline Cluster 4 & Wetar Utara, Wetar Timur, Kisar Utara, Lakor, Dawelor Dawera, P. Wetang, \\
\hline
\end{tabular}

\subsection{Pemilihan Metode Pengelompokkan Terbaik}

Untuk mengetahui metode mana yang mempunyai kinerja terbaik, maka digunakan kriteria dua nilai simpangan baku, yaitu rata-rata simpangan baku dalam cluster $S_{W}$ dan simpangan baku antar cluster $S_{B}$. Metode terbaik mempunyai nilai rasio antar simpangan baku dalam cluster dengan simpangan baku antar cluster yang terkecil. Semakin kecil nilai $S_{W}$ dan semakin besar nilai $S_{B}$ maka akan memiliki kinerja yang baik, artinya mempunyai homogenitas atau kesamaan yang tinggi antar anggota dalam satu cluster [11]. Rumus rata-rata simpangan baku dalam cluster $S_{W}=\frac{\sum_{k=1}^{n} S_{k}}{n}$ dengan $n=$ banyaknya cluster yang terbentuk dan $S_{k}=$ simpangan baku cluster ke- $k$. Sedangkan rumus simpangan baku antar cluster $\left(S_{B}\right)$ adalah $S_{B}=\left[\frac{\sum_{k=1}^{n}\left(\overline{\mathrm{X}}_{k}-\overline{\mathrm{X}}\right)^{2}}{n-1}\right]^{\frac{1}{2}}$ dengan $\overline{\mathrm{X}}_{k}=$ rataan cluster ke- $k$ dan $\bar{X}=$ rataan keseluruhan cluster. Setelah dilakukan perhitungan, diperoleh nilai rasio seperti dalam Tabel 4, berikut:

Tabel 4. Pemilihan Metode Pengelompokkan Terbaik

\begin{tabular}{|c|c|c|c|}
\hline \multirow{2}{*}{ Cluster } & \multicolumn{2}{|c|}{ Rasio } & \multirow{2}{*}{ Metode Terbaik } \\
\cline { 2 - 3 } & SOM & Biplot & \\
\hline 4 Cluster & 0,4426 & 0,4257 & Biplot \\
\hline
\end{tabular}

Berdasarkan Tabel 4, menunjukkan bahwa untuk pengelompokkan 17 kecamatan di Kabupaten MBD berdasarkan karakteristik kemiskinan terlihat bahwa metode Biplot menunjukkan hasil yang lebih baik daripada metode SOM karena memiliki rasio yang lebih kecil yaitu 0,4257 dibandingkan dengan nilai rasio SOM yaitu 0,4426. Karena metode Biplot merupakan metode terbaik dalam pengelompokkan kecamatan di kabupaten MBD berdasarkan karakteristik kemiskinan makan langkah selanjutnya adalah melakukan analis lebih lanjut.

\subsection{Hasil Analisis Biplot}

Berdasarkan prosedur analisis biplot diperoleh hasil berupa biplot seperti pada Gambar 2, berikut:

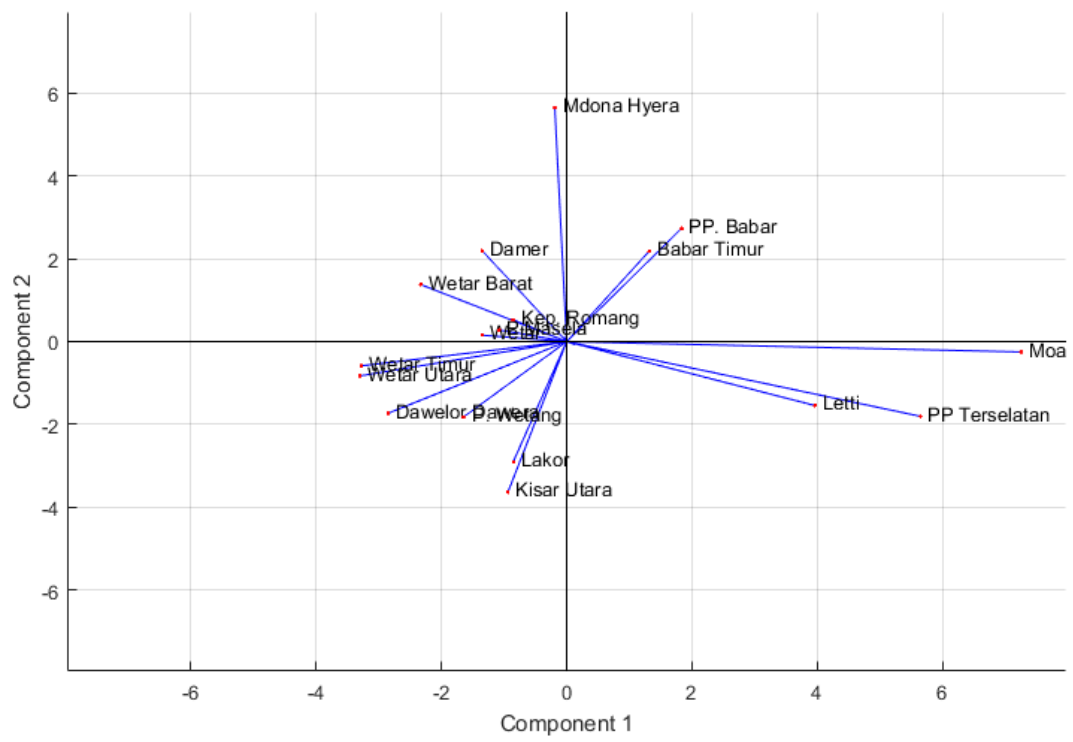

Gambar. 2 Grafik Biplot 
Pada penelitian ini dihasilkan grafik biplot dengan $\alpha=1$, alasan terpilihnya biplot dengan $\alpha=1$ yaitu hasil kali matriks koordinat objek $(G)$ dan matriks koordinat variabel $(H)$ sama dengan elemen-elemen pada matriks data awal. Sehingga biplot dalam penelitian ini merupakan biplot RPM (Row Metric Preserving) atau biplot komponen utama. Biplot RPM ini digunakan untuk menduga jarak Euclidean secara optimal. Berdasarkan tampilan biplot di atas maka diperoleh bahwa cluster 1 yang terdiri dari kecamatan Pulau-Pulau Terselatan, Letti dan Moa merupakan merupakan cluster dengan karakteristik kemiskinan yang rendah. Sedangkan cluster 4 yang terdiri dari kecamatan Wetar Utara, Wetar Timur, Kisar Utara, Lakor, Dawelor Dawera dan P. Wetang merupakan cluster dengan tingkat kemiskinan yang sangat tinggi. Selanjutnya untuk cluster 3 yang terdiri dari kecamatan Pulau Masela, Mdona Hyera, Kepulauan Romang, Damer, Wetar dan Wetar Barat merupakan cluster tingkatan kemiskinan yang cukup tinggi, sedangkan untuk cluster ke 2 terdiri dari kecamatan Pulau-Pulau Babar dan Babar Timur tergolong cluster tingkatan kemiskinan yang sedang.

\subsubsection{Kedekatan antar objek}

Informasi ini dijadikan paduan untuk mengetahui kecamatan yang memiliki kemiripan karakteristik dengan kecamatan lainnya. Kecamatan yang berada pada kuadran yang sama dikatakan memiliki kesamaan karakteristik kemiskinan yang cukup dekat jika dibandingkan dengan kecamatan yang berada pada kudran yang berbeda.

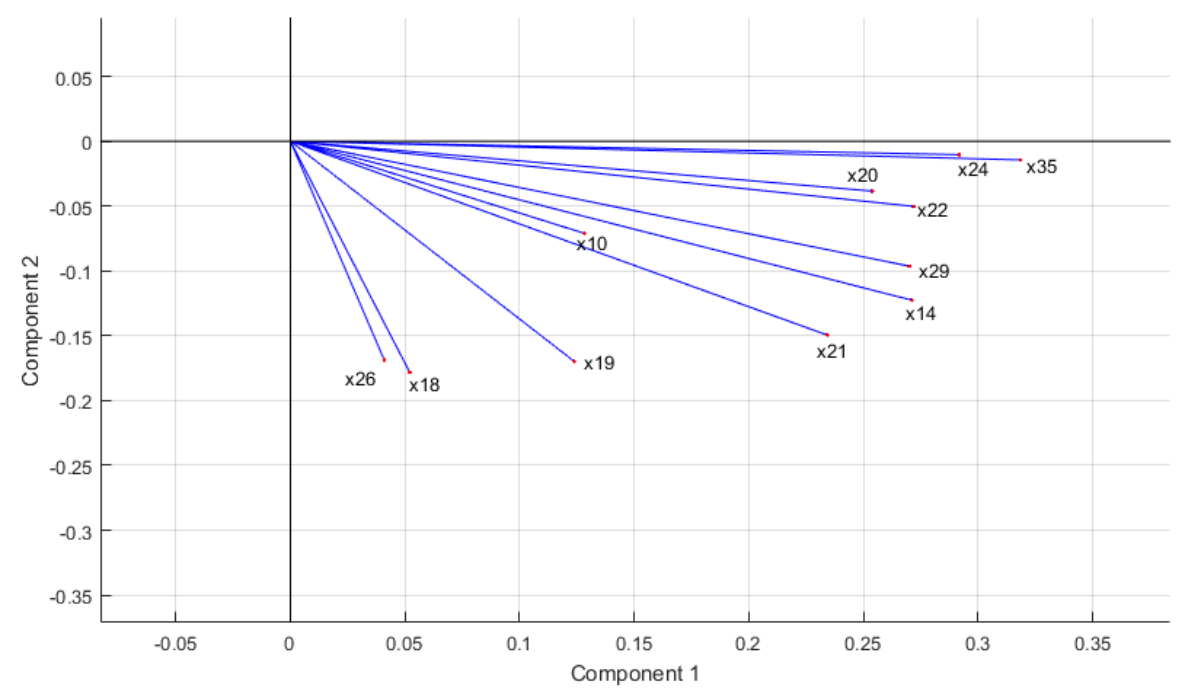

Gambar. 3 Grafik Karakteristik Kemiskinan di Cluster 1

Selain itu juga kesamaan karakteristik kemiskinan dapat ditentukan melalui jarak Euclidean, semakin kecil nilai jarak Euclidean maka semakin dekat kedua objek tersebut. Berdasarkan Gambar 3 - Gambar 6, maka dapat dijelaskan karakteristik kemiskinan yang mempengaruhi sehingga 17 kecamatan di kabupaten MBD dikelompokkan dalam cluster yang berada pada kuadran yang sama yaitu sebagai berikut:

1. Cluster 1, diantaranya kecamatan Pulau-Pulau Terselatan, Letti dan Moa memiliki kemiripan pada:

Faktor Geografis dan akses

$X_{10}$ : Luas areal tanaman kacang tanah, yaitu memiliki luas areal tanaman kacang tanah yang besar dibandingkan kecamatan yang lain.

$X_{14}$ : Panjang jalan dalam kondisi baik, yakni sebagian besar daerah di kecamatan memiliki kondisi jalan yang sudah beraspal.

Faktor Sumber Daya Manusia (SDM) dan Sosial Ekonomi Penduduk

$X_{18}$ : Laju pertumbuhan penduduk, dimana laju pertumbuhan penduduk di kecamatan pada cluster 1 ini sangat tinggi dibandingkan kecamatan yang lain.

$X_{19}$ : Kepadatan penduduk per $\mathrm{km}^{2}$, yaitu kepadatan penduduk sangat tinggi dibandingkan kecamatan yang lain.

$X_{20}$ : Rasio jumlah guru dan banyaknya Sekolah Dasar sangat baik yaitu rata-rata 8,68 di atas ratarata keseluruhan yakni 5,74. 
$X_{21}$ : Rasio jumlah guru dan banyaknya sekolah SMP sangat baik yaitu rata-rata 9,94 di atas rata-rata keseluruhan yakni 4,82 .

$X_{22}$ : Rasio jumlah guru dan banyaknya sekolah SMA sangat baik yaitu rata-rata 19,83 di atas ratarata keseluruhan yakni 6,97.

$X_{24}$ : Jumlah tenaga kesehatan yang memadai yaitu rata-rata 47 tenaga kesehatan di tiap kecamatan

$X_{26}$ : Persentase status gizi buruk balita yang cukup besar yaitu rata-rata $6,12 \%$

$X_{29}$ : Populasi ternak yang sangat banyak yaitu rata-rata 16129 , jauh di atas rata-rata yakni 7105 .

Sarana dan Prasarana

$X_{35}$ : Jumlah koperasi yang banyak yakni rata-rata 21 koperasi di setiap kecamatan

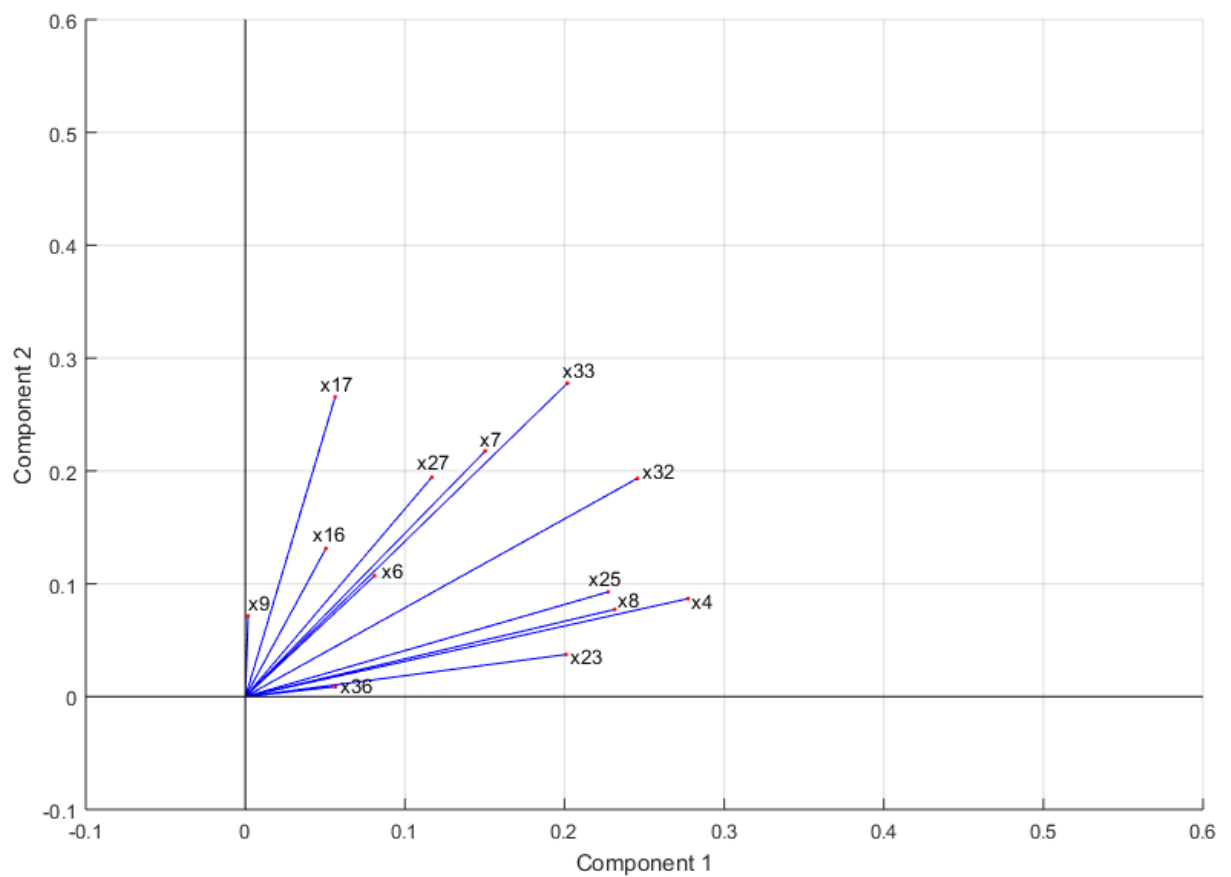

Gambar. 4 Grafik Karakteristik Kemiskinan di Cluster 2

2. Cluster 2, diantaranya kecamatan Pulau-Pulau Babar dan kecamatan Babar Timur memiliki kemiripan pada:

Faktor Geografis dan akses

$X_{4}$ : Banyaknya desa cukup banyak yaitu rata-rata 12 desa di tiap kecamatan dan masih di atas ratarata keseluruhan yakni 9 desa per kecamatan

$X_{6}$ : Luas areal padi sawah, yaitu rata-rata setiap kecamatan pada cluster 2 memiliki luas areal sawah yang besar dibandingkan kecamatan yang lain.

$X_{7}$ : Luas areal tanaman jagung, yaitu rata-rata setiap kecamatan pada cluster 2 memiliki luas areal tanaman jagung yang besar dibandingkan kecamatan yang lain.

$X_{8}$ : Luas areal tanaman ketela pohon yang cukup luas karena masih di atas rata-rata keseluruhan

$X_{9}$ : Luas areal tanaman ketela rambat, yaitu rata-rata setiap kecamatan pada cluster 2 memiliki luas areal ketela rambat yang besar dibandingkan kecamatan yang lain.

$X_{16}$ : Panjang jalan dalam kondisi sedang, yakni sebagian besar daerah di kecamatan pada cluster 2 memiliki kondisi jalan yang masih urpil.

Faktor Sumber Daya Manusia (SDM) dan Sosial Ekonomi Penduduk

$X_{17}$ : Tingkat perkembangan desa (swadaya, swakarsa, swasembada) sangat tinggi dibandingkan kecamatan yang lain 
$X_{23}$ : Rasio jumlah guru dan banyaknya sekolah SMK cukup rendah yaitu rata-rata 4 guru di tiap sekolah walaupun masih di atas rata-rata keseluruhan yaitu 3 guru tiap sekolah.

$X_{25}$ : Tenaga Usaha Perbaikan Gizi Keluarga (UPGK) masih sangat rendah yaitu rata-rata 51 orang di tiap kecamatan dimana angka ini masih dibawah rata-rata keseluruhan yaitu 53 orang per kecamatan.

$X_{27}$ : Persentase peserta $\mathrm{KB}$ aktif terhadap jumlah pasangan usia subur sangat tinggi yaitu rata-rata $24,96 \%$ di atas rata-rata keseluruhan yakni $12,35 \%$.

Sarana dan Prasarana

$X_{32}$ : Jumlah fasilitas kesehatan (puskesmas dan posyandu) tergolong cukup yaitu rata-rata 18 fasilitas kesehatan di tiap kecamatan dan masih berada di atas rata-rata keseluruhan yaitu 12 fasilitas kesehatan di tiap kecamatan

$X_{33}$ : Jumlah Klinik Keluarga Berencana (KKB) dan Pos Pelayanan Keluarga Berencana Desa (PPKBD) rata-rata 1 klinik di tiap kecamatan

$X_{36}$ : Sarana dan prasarana perhubungan laut dan udara rata-rata 1 sarana prasarana di tiap kecamatan

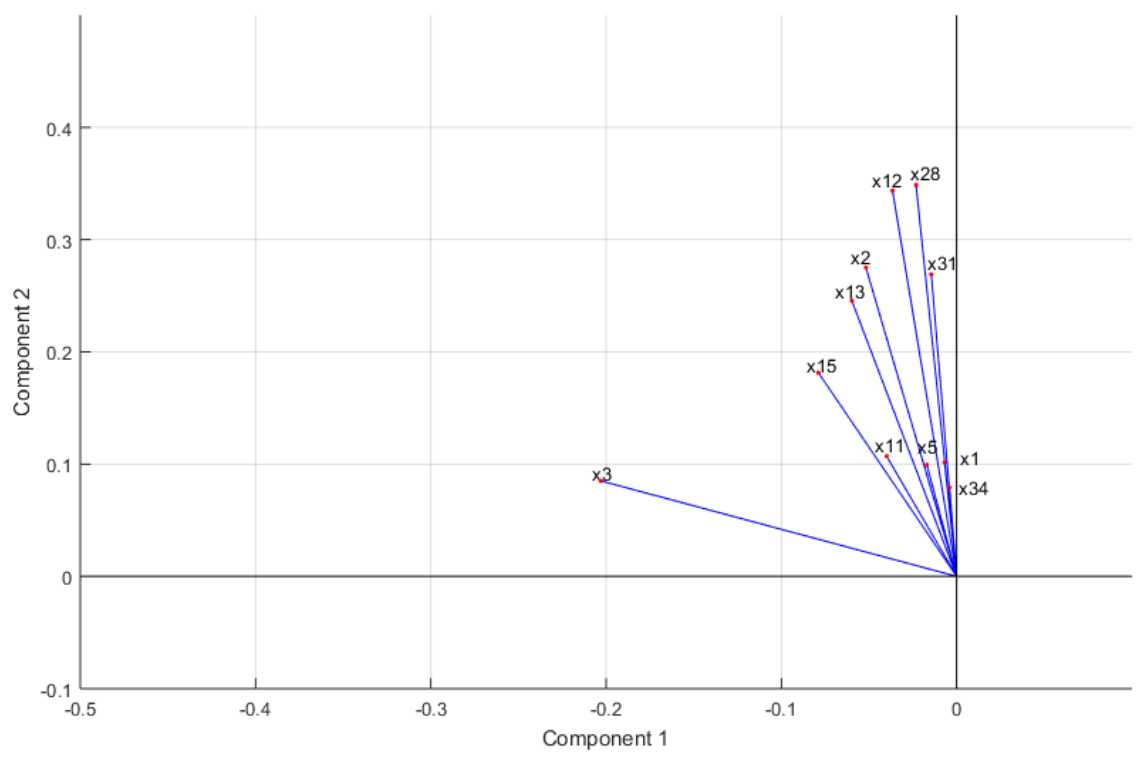

Gambar. 5 Grafik Karakteristik Kemiskinan di Cluster 3

3. Cluster 3, diantaranya kecamatan Pulau Masela, Mdona Hyera, Kepulauan Romang, Damer, Wetar dan Wetar Barat memiliki kemiripan pada:

Faktor Geografis dan akses

$X_{1}$ : Luas wilayah, dimana rata-rata luas wilayah kecamatan di cluster 3 sangat besar dibandingkan kecamatan yang lain.

$X_{2} \quad$ : Banyak pulau, yaitu bahwa rata-rata kecamatan di cluster 3 terdiri dari banyak pulau.

$X_{3} \quad$ : Jarak ibukota kabupaten MBD dengan ibu kota kecamatan di cluster 3 cukup jauh.

$X_{5} \quad$ : Luas areal padi ladang, dimana rata-rata luas areal padi ladang pada kecamatan di cluster 3 sangat besar dibandingkan kecamatan yang lain.

$X_{11}$ : Luas areal tanaman kacang hijau, dimana rata-rata luas areal tanaman jagung pada kecamatan di cluster 3 sangat besar dibandingkan kecamatan yang lain

$X_{12}$ : Luas tanaman perkebunan (kelapa, cengkih, pala, kopi, kakao dan jambu mete) setiap kecamatan di cluster 3 cukup luas

$X_{13}$ : Luas potensi lahan budidaya laut, dimana rata-rata luas potensi lahan budidaya laut setiap kecamatan pada cluster 3 ini sangat besar

$X_{15}$ : Panjang jalan dalam kondisi rusak (tanah/belum tembus), dimana rata-rata setiap daerah pada kecamatan di cluster 3 masih memiliki jalan dalam kondisi rusak. 
Faktor Sumber Daya Manusia (SDM) dan Sosial Ekonomi Penduduk:

$X_{28}$ : Produksi tanaman perkebunan, dimana rata-rata desa di kecamatan dalam cluster 3 yang memproduksi tanaman perkebunan masih cukup tinggi yaitu 580,03 ton masih di atas rata-rata yakni sebesar 333,94 ton.

$X_{31}$ : Banyaknya produksi rumput laut, dimana rata-rata desa di kecamatan dalam cluster 3 banyak yang memproduksi rumput laut

Sarana dan Prasarana

$X_{34}$ : Jumlah perahu/kapal, dimana rata-rata jumlah perahu/kapal pada setiap desa di kecamatan dalam cluster 3 sangat banyak dan di atas rata-rata keseluruhan.

4. Cluster 4, diantaranya kecamatan Wetar Utara, Wetar Timur, Kisar Utara, Lakor, Dawelor Dawera dan P. Wetang memiliki kemiripan variabel $X_{30}$ yaitu populasi unggas yang sangat banyak yaitu rata-rata 10988 unggas di tiap kecamatan dan berada di atas rata-rata keseluruhan yaitu 4989.

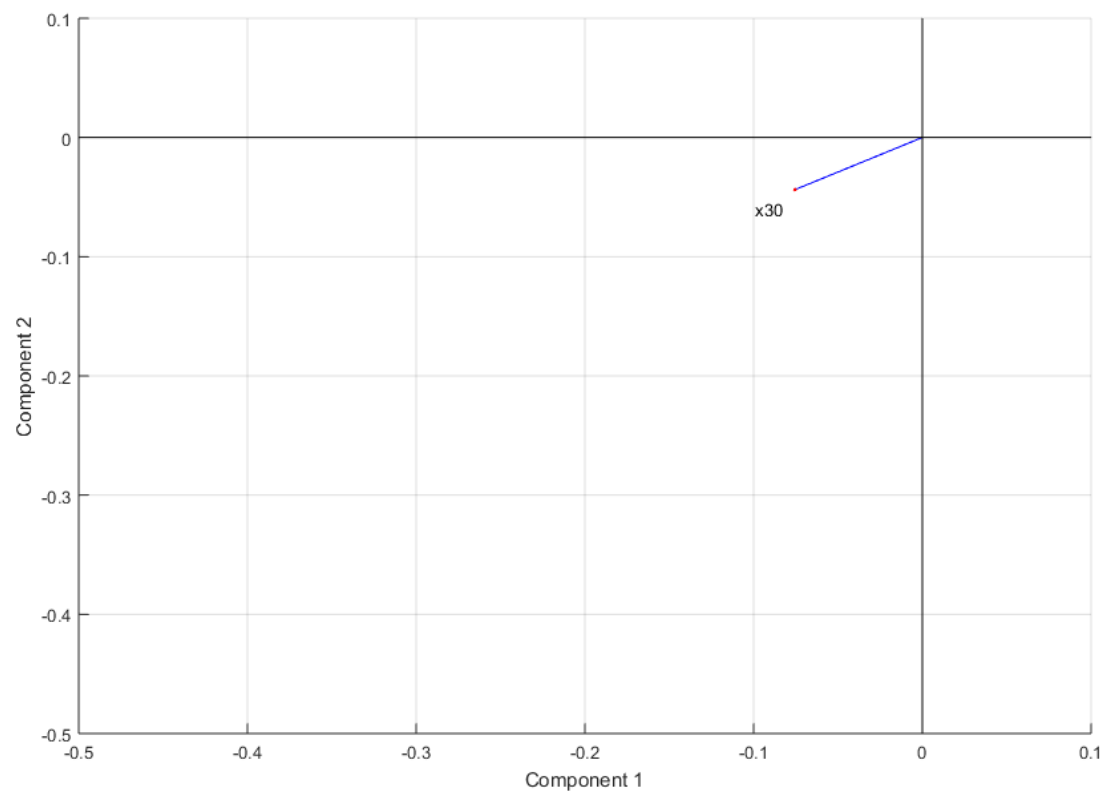

Gambar. 6 Grafik Karakteristik Kemiskinan di Cluster 4

\subsubsection{Keragaman Variabel ( Karakteristik Kemiskinan)}

Informasi ini digunakan untuk menentukan karakteristik kemiskinan di setiap wilayah kecamatan. Dengan ini, bisa diperkirakan pada karakteristik kemiskinan yang mana strategi harus ditingkatkan dalam rangka menurunkan angka kemiskinan, dan juga sebaliknya.

Cluster 4 yang terdiri dari 6 kecamatan, yaitu Wetar Utara, Wetar Timur, Kisar Utara, Lakor, Dawelor Dawera dan P. Wetang merupakan cluster dengan karakteristik kemiskinan tertinggi. Faktor-faktor yang mempengaruhi sehingga cluster ini tergolong ke dalam cluster dengan tingkat kemiskinan tertinggi adalah sebagai berikut:

a. Sebagian besar jalan belum dalam kondisi baik (aspal) dan masih dalam kondisi urpil

b. Tingkat perkembangan desa (swadaya, swakarsa, swasembada) masih sangat rendah

c. Rasio jumlah guru dan banyaknya SD masih sangat sedikit yakni rata-rata jumlah guru pada suatu SD hanya 4-5 orang

d. Rasio jumlah guru dan banyaknya sekolah SMP masih sangat sedikit yakni rata-rata jumlah guru pada suatu SMP hanya 3-4 orang

e. Rasio jumlah guru dan banyaknya sekolah SMA masih sangat sedikit yakni rata-rata jumlah guru pada suatu SMA hanya 2-3 orang

f. Hampir di setiap kecamatan tidak ada bangunan sekolah SMK

g. Jumlah tenaga kesehatan masih sedikit yakni rata-rata di setiap kecamatan hanya ada 11 orang tenaga kesehatan

h. Tenaga Usaha Perbaikan Gizi Keluarga (UPGK) masih sedikit yakni rata-rata di setiap kecamatan hanya ada 31 orang tenaga UPGK 
i. Jumlah fasilitas kesehatan (puskesmas dan posyandu) masih sedikit yakni di setiap kecamatan ratarata hanya 7 fasilitas kesehatan

j. Tidak tersedianya Klinik Keluarga Berencana (KKB) dan Pos Pelayanan Keluarga Berencana Desa (PPKBD) di setiap kecamatan

k. Jumlah koperasi yang masih sangat sedikit yaitu rata-rata hanya 2 koperasi di setiap kecamatan

Sedangkan faktor-faktor yang merupakan karakteristik kemiskinan yang juga turut mempengaruhi sehingga cluster 3 tergolong ke dalam cluster dengan tingkat kemiskinan yang cukup tinggi adalah sebagai berikut:

a) Kondisi jalan yang masih rusak (tanah/belum tembus)

b) Rasio jumlah guru dan banyaknya sekolah SMP masih sangat sedikit, yaitu rata-rata jumlah guru pada suatu SMP hanya 3 orang

c) Hampir di setiap kecamatan tidak ada bangunan sekolah SMK. Untuk kecamatan yang ada sekolah SMK, ketersediaan guru masih sangat sedikit yaitu rata-rata hanya ada 2 guru dalam satu sekolah.

d) Jumlah tenaga kesehatan masih sedikit yakni rata-rata di setiap kecamatan hanya ada 9 orang tenaga kesehatan.

\section{KESIMPULAN}

1. Hasil pengelompokkan menggunakan metode Biplot lebih baik jika dibandingkan dengan hasil pengelompokkan menggunakan metode SOM karena memiliki rasio yang lebih kecil. Adapun hasil pengelompokkan yang diperoleh adalah sebagai berikut:

Cluster 1 Pulau-Pulau Terselatan, Letti, Moa

Cluster 2 Pulau-Pulau Babar, Babar Timur

Cluster 3 Pulau Masela, Mdona Hyera, Kepualauan Romang, Damer, Wetar, Wetar Barat,

Cluster 4 Wetar Utara, Wetar Timur, Kisar Utara, Lakor, Dawelor Dawera, Pulau Wetang,

2. Faktor-faktor yang mempengaruhi sehingga cluster 4 yang terdiri dari 6 kecamatan, yaitu Wetar Utara, Wetar Timur, Kisar Utara, Lakor, Dawelor Dawera dan Pulau Wetang merupakan cluster dengan karakteristik kemiskinan tertinggi adalah sebagai berikut:

a. Sebagian besar jalan belum dalam kondisi baik (aspal) dan masih dalam kondisi urpil.

b. Tingkat perkembangan desa (swadaya, swakarsa, swasembada) masih sangat rendah

c. Rasio jumlah guru dan banyaknya SD masih sangat sedikit yakni rata-rata jumlah guru pada suatu SD hanya 4-5 orang.

d. Rasio jumlah guru dan banyaknya sekolah SMP masih sangat sedikit yakni rata-rata jumlah guru pada suatu SMP hanya 3-4 orang.

e. Rasio jumlah guru dan banyaknya sekolah SMA masih sangat sedikit yakni rata-rata jumlah guru pada suatu SMA hanya 2-3 orang.

f. Hampir di setiap kecamatan tidak ada bangunan sekolah SMK.

g. Jumlah tenaga kesehatan masih sedikit yakni rata-rata di setiap kecamatan hanya ada 11 orang tenaga kesehatan.

h. Tenaga Usaha Perbaikan Gizi Keluarga (UPGK) masih sedikit yakni rata-rata di setiap kecamatan hanya ada 31 orang tenaga UPGK.

i. Jumlah fasilitas kesehatan (puskesmas dan posyandu) masih sedikit yakni di setiap kecamatan rata-rata hanya 7 fasilitas kesehatan.

j. Tidak tersedianya Klinik Keluarga Berencana (KKB) dan Pos Pelayanan Keluarga Berencana Desa (PPKBD) di setiap kecamatan.

$k$. Jumlah koperasi yang masih sangat sedikit yaitu rata-rata hanya 2 koperasi di setiap kecamatan. 


\section{DAFTAR PUSTAKA}

[1] A. A. Matjik and I. M. Sumertajaya, "Sidik Peubah Ganda Dengan Menggunakan SAS", Bogor: IPB Press, 2011.

[2] BPS Provinsi Maluku, "Statistik Daerah Provinsi Maluku", Ambon, 2017.

[3] BPS Maluku Barat Daya, "Indikator Kesejahteraan Rakyat Kabupaten Maluku Barat Daya", Tiakur, 2016.

[4] BPS Maluku Barat Daya, "Kabupaten Maluku Barat Daya Dalam Angka", Tiakur, 2017.

[5] D. Gil, M. Johnsson, J. M. G. Chamizo, P. A. Soriano and F. D. Ruiz, "Application of Artificial Neural Networks in the Diagnosis of Urological Dysfunctions," Expert Systems with Applications, Vol. 36, No. 3, p. 5754-5760, 2009.

[6] E. F. Rifkhatussa'diyah, H. Yasin and A. Rusgiyono, "Analisis Principal Component Biplots Pada Bank Umum Persero yang Beroperasi Di Jawa Tengah," in Prosiding Seminar Nasional Statistika, Semarang, 2013.

[7] H. C. Chou, C. H. Cheng and J. R. Chang, "Extracting Drug Utilization Knowledge Using Self-Organizing Map and Rough Set Theory," Expert Systems with Applications, Vol. 33, No. 2, pp. 499-508, 2007.

[8] I. T. Jollife, "Principal Component Analysis", New York: Springer-verlag, 2002.

[9] K. C. Y. \&. Y. S. Zhang, "Self-Organizing Feature Map for Cluster Analysis in Multi-disease Diagnosis," Expert Systems with Applications, Vol. 37, No. 9, pp. 6359-6367, 2010.

[10] L. Fausett, "Fundamentals of Neural Networks, Architecture, Algorithms, and applications", Prentice-Hall, 1994.

[11] M. J. Bunkers, \& J. R. Miller, "Definition of Climate Regions in The Northern Plains Using an Objective Cluster Modification Technuque," Journal of Climate, No. 9, pp. 130-146, 1996.

[12] S. Hidayat, "Pemodelan Desa Tertinggal di Jawa Barat Tahun 2005 dengan Pendekatan MARS," Jurusan Statistika FMIPA ITS, Surabaya, 2008.

[13] Z. A. Leleury and H. W. M. Patty, "Analisis Cluster dan Diagnosa Penyakit Menggunakan Jaringan Syaraf Tiruan," in Prosiding FMIPA Universitas Pattimura, Ambon, 2013.

[14] Z. A. Leleury and A. E. Wokanubun, "Analisis Biplot dan Pemetaan Karakteristik Kemiskinan di Provinsi Maluku," Barekeng: Jurnal ilmu matematika dan terapan, Vol. 9, No. 1, pp. 21-31, 2015. 